\title{
Predictive research methods of enamel and dentine for initial caries detection
}

\author{
Anatoly A Kunin, Irina A Belenova, Yury A Ippolitov, Natalia S Moiseeva* and Dmitry A Kunin
}

\begin{abstract}
Currently, various research methods of enamel and dentine for precautionary diagnostics of initial caries forms are developed; however, the vast majority of these do not provide objective criteria of caries diagnostics or are very difficult to perform. Therefore, the search of diagnostics and enamel research methods, which will allow predicting caries emergence and to carry out personalised prevention of this pathology, is necessary. In this review, modern diagnostic methods that allow understanding the main aspects of caries process, assess the risk of its development, and also suggest the possibility of emergency prevention of caries progression in the nearest future are presented.
\end{abstract}

Keywords: Predictive Diagnosis, Initial Caries, Individual Prevention, Light-Induced Fluorescence, Electrometry

\section{Review \\ Introduction}

Recently, after the foundation of European Association for Predictive, Preventive and Personalised Medicine (EPMA), which includes 44 countries of Europe, Asia and other parts of the world, a definite tendency has been formed in 'diagnostics', defining the significant importance of preventive diagnostic methods and personalised prevention [1]. Similarly, methods to estimate the initial stages and forms of pathological processes of the teeth, gingival tissues, oral mucosa, joints and bones of the maxillofacial region have gained importance. Among all tissue types of both maxillofacial region and other body tissues, tooth caries has been shown to be the most frequent disease. Therefore, the registration of teeth lesions especially at the young ages will prevent the failure of the protective properties of the body and consequently will show the necessity of modifying socio-economical risk factors such as oral hygiene procedures, age-related factors, residence and dwelling place and social strata. In this review, the main preventing issues of tooth caries by detecting its early signs are presented which will help both dental professionals and experts on diabetes, oncology, haematology and endocrinology to potentiate the researches of hard dental tissues at the organ pathology level [2].

\footnotetext{
* Correspondence: natazarova@yandex.ru

Therapeutic Dentistry Department, Faculty of Dentistry, Voronezh N.N. Burdenko State Medical Academy, Avenue of Revolution Str. 14, Voronezh, Russia
}

Comprehensive patient examination using the whole range of diagnostic methods is a crucial link for effective individual prevention of dental caries [3,4]. Diagnosis is defined as the section of medical science that outlines detection methods of different diseases and the patient's status in order to prescript the essential treatment and preventive measures [5]. Thus, the diagnosis in the narrow sense is patient examination for establishing of the disease diagnosis after the appearance of the initial symptoms. In contrast, individual caries prevention programme should be detached from the whole variety of methods since it should allow not only identifying available disease but also predict the pathology emergence or diagnose the beginning of illness at early preclinical stage, even when the pathology consecution have no clinical manifestations [6]. Accordingly, the programme of individual caries prevention is based primarily on data obtained during the diagnostic manoeuvres realisation, which allows predicting of caries. The determination of precarious status can be established by determining caries development signs and risk factors. Among the well-known and widely used methods in dentistry, it is necessary to allocate those that are capable to characterise the systematic relationship of 'salivaplaque-enamel' as an important link in the dental caries pathogenesis $[7,8]$.

Predictive diagnosis is a dynamic, multi-stage and multicomponent process based on research results, and individual prevention is highly effective if it has etiopathogenetic 
character concerning each patient taken separately [9]. In our opinion, improvement of the practicability of methodological aspects of clinical diagnostics at individual caries prevention implementation is extremely important on the following positions:

1. Implementation stages of medical-diagnostic and preventive measures

2. The possibility of existence and development of dentition diseases requiring high-priority intervention and other specialist's consultation

3. Formation of a prognostic diagnosis (diagnoses) on the basis of experts in other sections of dentistry

4. Competent creation of health care activities

5. The necessity of the use of a significant amount of diagnostics methods for diagnostic inference verification

6. The choice expediency of rational prevention and medical-diagnostic 'route' and profiling of patients

7. Optimum sequence definition on the importance of performance degree of diagnostic and treatment measures

All currently known research methods and indexes, including hygienic, gingival, and caries prediction, have long been tested in practice, are informative in such area, and add up to a full-fledged clinical picture of the patient's dental status [10]. Unfortunately, performing the full range of proposed diagnostic techniques in practice is not possible due to the high cost and spending a considerable time interval as a whole. Dentists are faced in a situation of insoluble problem, where the easiest way is to cure a cavity, instead of looking for its causes and ways of risk factors elimination $[11,12]$.

\section{Early caries forms detection methods and findings}

The basis of tooth diseases diagnosing is the results summation of all its tissues studies, as well as other elements of dental-maxillofacial region, occlusion and articulation $[13,14]$. In other words, the diagnosis of 'caries' does not exclude the possibility of other maxillofacial diseases in patient and, therefore, does not relieve other physicians, which may seem unrelated at first glance, from the diagnosis and prevention of tooth caries, and once again emphasises the necessity of the individualisation of all measures held by the dentist [15].

Several studies [16-18] suggest that the initial demineralisation process of enamel occurring in the subsurface has no clinical manifestations which can be seen with the eyes and turns up as a preclinical stage of caries process development [19]. Thus, in our view, a special set of methods is necessary, including a variety of techniques, which characterises the hard dental tissues status at different precarious and caries stages [20,21]. For the purpose of timely diagnosis, prevention and personalised approach to the treatment of primary caries, a detailed study of the biochemical processes taking place in the structure of the tooth enamel and dentine in health and pathology is necessary $[22,23]$.

\section{Enamel apertures, tunnels, and bridges}

In 1995 at the dentistry Department of Voronezh N.N. Burdenko State Medical Academy (VSMA), Professor A.A. Kunin et al. revealed new structural formations of enamel with the help of actual high-technology research methods. This previously unknown structure was the presence of apertures on the enamel surface, leaving inside the tooth in parallel of the enamel prism bunches [24]. Using scanning electron microscopy, the researchers established that these apertures penetrated through the dentine in some areas of enamel-dentine border [25]. The amount of such apertures in enamel surface at young age is high, but their quantity is reduced with the increasing age as a result of various damaging factors. Normally, these apertures have a diameter equal to 1 to $1.5 \mu \mathrm{m}$, increasing with age up to $3 \mu \mathrm{m}$ (Figures 1, 2 and 3), with the reduction of their quantity [26]. Especially interesting is the identification of so-called 'enamel bridges' which are the penetrations of enamel 'appendage' into the dentine with preservation of 'tunnel' structure. In the presence of carie0073, these grooves or 'bridges' into the dentine can be broken; therefore, receiving mineral and organic compounds becomes complicated. There is only one access of necessary components for the preservation of tooth activity through a root canal [27].

There are numerous researches suggesting extensive information on the different changes in the tooth enamel. This information includes various data such as the initial changes existent in the surface structure of enamel and the parameters of the unit cell of enamel crystals [28,29]. However, none of these available data provide strong evidence on the importance of structures through the enamel.

\section{Cariogenic plaque}

The mechanism of the tooth metabolic processes in the demineralisation and remineralisation of enamel, which is the participation of enamel structures such as tunnels and bridges, is strongly affected by the activity of cariogenic plaque. Normally, the demineralisation and remineralisation processes are in a condition of dynamic balance in oral cavity, but in the presence of cariogenic factors, this balance shifts towards demineralisation [30,31]. The caries resistance of enamel depends on internal and external factors, but one of the main factors is the microbial dental plaque.

Today, the increased prevalence of caries and the high levels of cariogenic tooth plaque require individual 


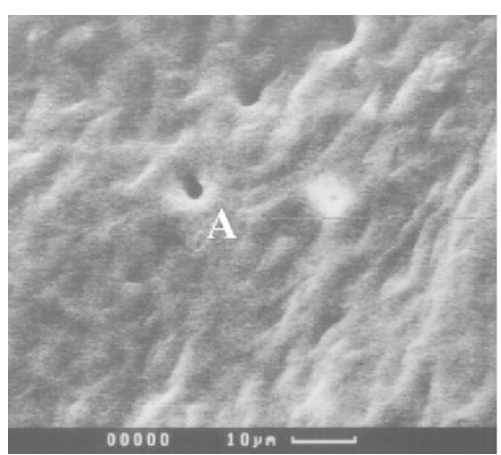

A

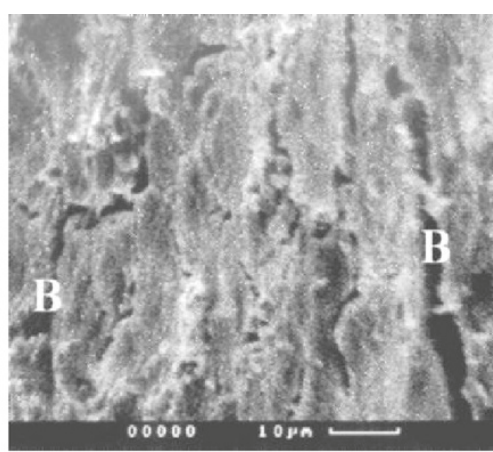

B

Figure 1 Permanent tooth enamel. (A) Enamel opening. (B) Enamel tunnel.

approaches to the diagnosis and treatment of dental disease $[32,33]$. The high degree of cariogenic plaque subsequently leads to the formation of high-risk groups for caries development among the population of our country. Depending on the level of cariogenic plaque, the intensity of tooth plaque colouring by methylene red solution is determined according to a typographic scale as follows: 0 to 20, easy; 21 to 40, medium; and 41 to 60, heavy degree of cariogenicity. Thereby, the individual prevention directed on elimination of a cariogenic situation in an oral cavity is necessary [34-36].

\section{Short-chain fatty acids}

The pathogenic significance and physiological role of dental plaque should be considered to determine the correct strategy for its removal. Despite indisputable proofs of the infectious carious nature, infection realisation in carious process is not always observed. Therefore, the oral microflora can be divided into two categories: cariogenic and non-cariogenic. According to some scientists, 'aggression' of cariogenic bacteria is defined by a developing ecological situation in a dental plaque. The way of identification of a

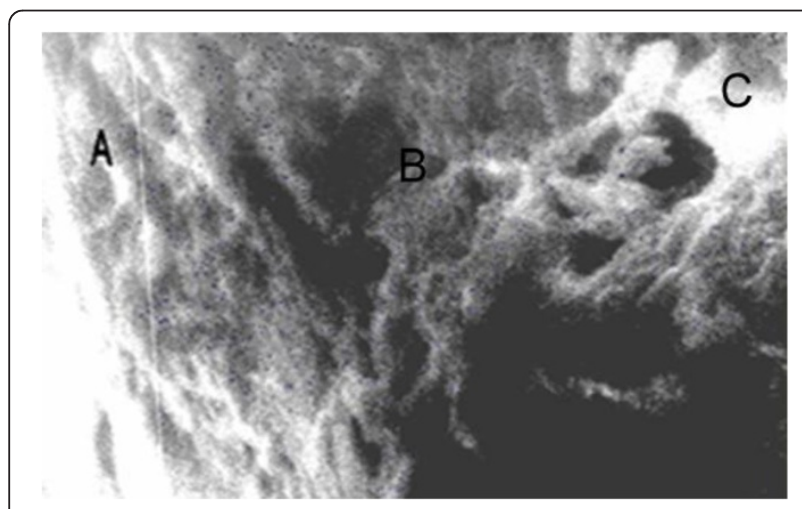

Figure 2 Tooth slice, cementoenamel line $(\times 5,000)$. (A) Enamel, (B) enamel bridge and (C) dentin. cariogenic and non-cariogenic tooth plaque in clinical practice is necessary $[37,38]$. The colonisation resistance of the oral mucous membranes is provided by the microflora metabolites, which include short-chain fatty acids (SCFA) such as acetic, propionic, isobutyric, isovaleric, valeric, izocapronic and capronic acid. SCFA, in parallel with the local immune system, play an important role in the stability resistance of the oropharynx epithelium, where the microflora of dental plaque has a specific contribution to the integral factors of bacterial metabolites in the oral fluid. The differentiation of the SCFA maintenance content in a tooth plaque is necessary for definition of enamel caries resistance. For this purpose, smears of tooth plaque are prepared on glass slide plates prepared by a drop of ferric chloride. After drying the glass over a torch flame (for the hydrolysis reaction of ferric acetate to acetic and propionic acids), the smear is evaluated by its colour, from brown (high content of SCFA) to light brown (low content of SCFA). For objective assessment of this method, dub preparation was subjected to microscopy investigation, digitalising the image using a video camera Sony MTV62W1P (Minato, Tokyo, Japan) [39]. The optical density

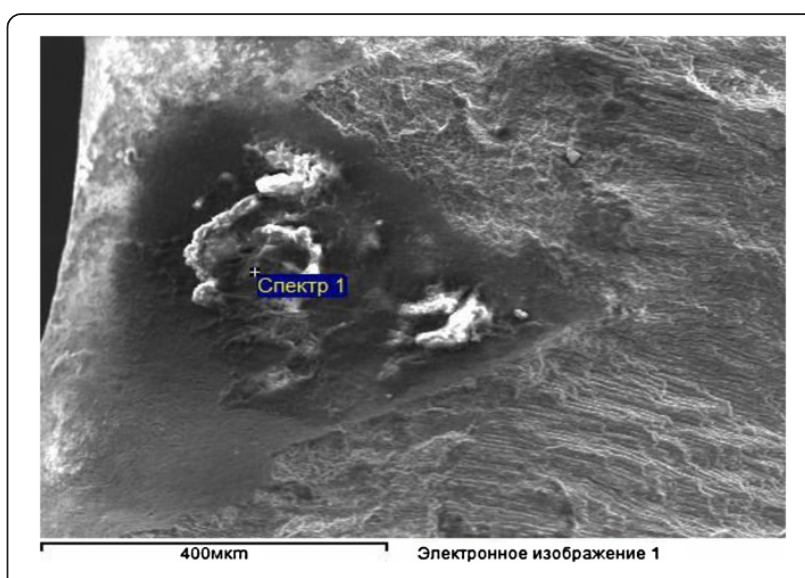

Figure 3 Enamel chip at subsurface demineralisation area. 
calculation of the dab preparation sites in the image analysis was performed using an image tool for Windows 3.0 with the Lambert-Bier formula. Previous researches stated that the reduction of the optical density of smears can signal the presence of caries. Depending on the optical density of smears obtained from the patient's plaque substrate, it is necessary to review the individual approach to oral hygiene [40].

Undoubtedly, the selection of individual hygiene means, taking into account particular properties of cariogenic situation in the mouth, will be a significant addition in the dental caries prevention. However, it is obvious that the problem of caries cannot be solved only with hygienic means [41]. The unity of enamel demineralisation and remineralisation mechanisms is that they are in dynamic balance, constantly occurring in-between oral liquid and enamel. The shift towards demineralisation means the beginning of the pathological structural and dynamic changes that occur in the enamel $[42,43]$.

\section{Organic and inorganic components of tooth}

Some researchers [44-46] reasonably indicate an exclusive importance of the calcium-phosphorus correlation in the tooth enamel as well as the fact that the higher the value is, the longer it keeps steady crystal structure and resists influencing of acids; i.e., the $\mathrm{Ca} / \mathrm{P}$ index is the criteria of tooth enamel stability, but there is no statement to what borderline value of the increase in $\mathrm{Ca} / \mathrm{P}$ index promotes the gain of enamel resistance [47]. Currently, there are new data concerning the participation of enamel and dentine organic structure in the enamel metabolism, which finally lead to the emergence of clinically defined carious affection, depending on the formation rate and development intensity on specific features of an organism.

Due to the emergence of data on an organic component of tooth structure $[48,49]$, the information of compound components and communication between the organic matrix and inorganic substances plays an important role in understanding of the processes occurring in hard dental tissues both in norm and at pathology [50]. Thus, carbohydrate and proteinaceous biopolymers and substance of protein nature objectively fill the interprismatic spaces and periodonto-blastic volume of dentinal tubules which are located in the tooth cement structures and also its soft fabrics, forming a physiological barrier to microorganisms and their metabolic products [51].

\section{Diagnostic methods}

The abundance of methods of diagnostics and research to identify enamel caries has not yet yielded optimum results, which depends on individual approaches, and also on the importance of these methods in this particular case. Therefore, up to date, various techniques for the diagnosis of primary caries are suggested [52,53]; however, the vast majority of them do not provide objective criteria of firm fabrics defeat at caries or are very difficult to perform. We would like to allocate some of them in the first place.

\section{Conductivity determination}

The method of conductivity determination of enamel is intended to improve the reliability and objectivity of the initial caries recognition and also subsequent stages of the caries process [54]. Numerous clinical researches [55] have shown that the measurement of the electrical conductivity of hard dental tissues allows more accurate differentiation of healthy regions from those being struck with caries, excluding thereby, hyper diagnostics, preventing from excessive harmful intervention.

In 1990, Ivanova proposed a method for determining the electrical conductivity of hard dental tissues based on the measurement of size of the microcurrent passing through firm tooth fabrics on certain surfaces (the enamel splint, hillocks, fissures, borders of an abutment filling, dental plaque in cervical areas, vestibular surface and pulpless teeth), which allows to detect latent fissure, recurrent caries, and tooth caries at the 'tooth-bracket' border and filling attachment [56]. Electrical conductivity of hard dental tissues was determined by electrodiagnostic device (DENTEST, GeosoftDent, Moscow, Russia). Measurements were carried out at a constant voltage of $4.26 \mathrm{~V}$, and the results of measurements were recorded in microamperes.

The method consists in careful drying of investigated teeth surface by air for $30 \mathrm{~s}$. Passive electrode (dental surgery mirror) is placed in the oral cavity, providing thus good contact of it with soft fabrics of oral tissues. In microsyringe the active electrode gains an electrolyte solution ( $10 \%$ solution of calcium chloride) with glycerin so that at the end of the needle, the meniscus of electrolyte is formed. The active electrode establishes on carefully dried and examined tooth site and writes down instrument readings. This method allows for determining the density of the crystal lattice of tooth enamel, which increases at enamel demineralisation with resistance loss. In its basis lie the inverse relations of tooth conductivity from mineralisation level of its fabrics. This method allows simple and accurate diagnosis of the initial latent caries, which confirms the clinical relevance of its usage in dentistry.

\section{Light-induced fluorescence}

The search for diagnostics and enamel research methods which can further estimate the data obtained at an assessment of conductivity is necessary, which include light-induced fluorescence. The basis of this caries diagnosis method is the phenomenon of porphyrin fluorescence - waste products of cariogenic microflora - 
under the influence of a laser or visible light of a certain wavelength [57-59].

In the method of laser fluorescence, a laser diode is used as a power source with a wavelength of $655 \mathrm{~nm}$ and light capacity equal or less than $1 \mathrm{MW}$. DIAGNOdent (KaVO Dental, Charlotte, NC, USA) is one of these devices with the same parameters. This device is used for the diagnosis of initial caries of fissures and vestibular surfaces of the tooth; however, the high price of the device and the complexity of the procedure (tooth preparing-cleaning before the diagnostic procedure) limit its routine use $[60,61]$.

For an assessment of light-induced fluorescence of hard dental tissues and primary dental caries diagnosis, we propose to use the domestic light-emitting-diode activator 'LED active', (MEDTORG+, Kirov, Russia), with a wavelength of $530 \mathrm{~nm}$ and illumination of 10,000 metre-candle, and also wavelength of $625 \mathrm{~nm}$ at the $140 \mathrm{MW} / \mathrm{cm}^{2}$ radiation power density. The activator's principle action is based on the application of light powerful light-emitting diodes with the big intensity of a luminescence of monochrome colour without a thermal component $[62,63]$.

At an inspection of smooth surfaces of enamel or visible cement of a root by means of radiation of green colour, the centre's initial demineralisation, in the form of change of fluorescence in the defeat centre, is most effectively diagnosed [64]. Using light radiation at inspection in determining fluorescence parameters, occlusal surfaces change to red colour long before demineralisation occurs and products of a metabolism of microorganisms are produced. The above metabolism of microorganisms in the centre of demineralisation differs in luminescence from the fluorescence of healthy fabrics [65]. Clinically, lightinduced fluorescence can be used for a choice of preventive tactics concerning tooth, as it allows distinguishing between healthy teeth and teeth with low and high risk of caries [66].

Further researches of hard dental tissues structural change in preclinical and early caries stages using novel methods, based on new physical approaches namely, the light-induced fluorescence and electrometry [67-69], are necessary in order to carry out large-scale researches on the prevention, early diagnosis and personalised treatment of caries and identification of the pathogenesis of its development and progression. In our opinion, the use of these techniques is essential for early diagnosis and prevention of tooth caries, which will significantly improve the accuracy and timeliness of diagnosis statement, and also the quality of treatment and preventive process. Comparison of the characteristics of clinical and laboratory parameters of intact enamel and at initial caries stage by current diagnostic methods is important, which will allow to predict emergence of caries and to carry out purposeful prevention of this pathology [70-72].
X-rays

If to mean preclinical diagnostics of the initial caries stage, there are methods capable 'to catch' demineralisation signs. These methods have to state remineralisation effect and confirm a complete enamel recovery, thereby optimising the development of remineralising therapy methods [73-75]. The above methods estimate them, but the most important thing is the determination of how the remineralisation occurs.

The most practiced and most reliable method is X-ray in identifying latent cavities by passing rays [76]. The identification of preclinical symptoms of caries is problematic today. Doctors now in most cases do not estimate the initial extent of demineralisation on the X-ray image though, if increased, is probably possible [77]. As a result of complex application of intraoral radiography, caries stages can be evaluated by five points with light-induced fluorescence and measurements of electric resistance of hard dental tissues [57].

\section{IKLORZ index}

Assessment of the clinical and laboratory evaluation of resistance of hard dental tissues (IKLORZ) [78] is defined as the relation of the sum of the caries points to the total number of examined teeth, and this ratio is calculated using the formula

$$
I_{\mathrm{IKLORS}}=\frac{\sum R 1+\sum R 2+\sum R 3+\sum R 4}{32},
$$

where $I_{\text {IKLORS }}$ is the index of clinical assessment of hard dental tissues; $R 0$ is the caries at white spot stage; $R 1$ is the superficial caries $1 ; R 2$ is the superficial caries $2 ; R 3$ is the average caries; $R 4$ is the deep caries.

So for example, in an examination of a patient with 32 teeth, if there are fissure caries within enamel of two molar teeth and initial caries on three teeth in the form of a white spot, the calculation of a clinical assessment IKLORS index of firm fabrics status in this patient shows

$$
I_{\text {IKLORS }}=\frac{2+2+1+1+1}{32}=0.22 .
$$

Thus, the index of clinical assessment of hard dental tissues of the patient reaches the value of 0.22 .

The given researches convincingly show that increase of an index value through a certain period refers to an unfavourable carious gain in oral cavity and index reduction is related to adequate treatment and preventive measures [30].

\section{Properties of an ideal diagnostic caries technique}

The search of new highly effective diagnostic and preventive techniques at initial caries of teeth is, today, a priority problem of precautionary and preventive dentistry [79-81]. 
The important point is the selection the most informative and important method among the common list of diagnostic tests. By exploring all possible ways of improving the caries diagnosis, we came to the conclusion that in this case, the most urgent is the development of an automated procedure based on mathematical methods for solving problems. This procedure must include the following:
1. The totality formation of clinical caries signs towards the selection of most informative indicators with the highest diagnostic value and determination of their sequence on practical reception.

2. The allocation of the main clinical and anamnesis indicators which promote caries disease in order to form groups of patients [82-84].

Table 1 Forecasting methods of caries and identifying factors inspiring its emergence

\begin{tabular}{|c|c|c|c|}
\hline Number & Method & $\begin{array}{l}\text { Structure/ } \\
\text { component }\end{array}$ & Factor that potentiate caries development \\
\hline 1 & Polling & - & - \\
\hline 2 & Inspection, probe & - & - \\
\hline 3 & Definition of the caries intensity & $\begin{array}{l}\text { Hard dental } \\
\text { tissues }\end{array}$ & Caries susceptibility of enamel and dentine \\
\hline 4 & Definition of the plaque quantity & Teeth enamel & $\begin{array}{l}\text { Local enamel demineralisation, retrogression of oral fluid remineralising } \\
\text { ability }\end{array}$ \\
\hline 5 & Definition of plaque formation rapidity & Teeth enamel & $\begin{array}{l}\text { Local enamel demineralisation, retrogression of oral fluid remineralising } \\
\text { ability }\end{array}$ \\
\hline 6 & Definition of tooth plaque cariogenicity & Teeth enamel & $\begin{array}{l}\text { Local enamel demineralisation, retrogression of oral fluid remineralising } \\
\text { ability }\end{array}$ \\
\hline 7 & $\begin{array}{l}\text { Definition of enamel functional status } \\
\text { (TER test) }\end{array}$ & Teeth enamel & Level of enamel caries' susceptibility \\
\hline 8 & $\begin{array}{l}\text { Clinical evaluation of remineralisation speed } \\
\text { in enamel (CDERS test) }\end{array}$ & Teeth enamel & Level of enamel caries' susceptibility \\
\hline 9 & Acidic enamel biopsy & Teeth enamel & Level of enamel caries' susceptibility \\
\hline 10 & X-ray spectrum microanalysis & $\begin{array}{l}\text { Teeth enamel } \\
\text { and dentine }\end{array}$ & $\begin{array}{l}\text { Low level of macroelements and/or microelements, influence on enamel } \\
\text { caries' resistance }\end{array}$ \\
\hline 11 & Electric pulp test & Teeth pulp & Rise or fall of pulp affectability and its influence on enamel caries' resistance \\
\hline 12 & $\begin{array}{l}\text { Electrometric definition of hard dental } \\
\text { tissues }\end{array}$ & $\begin{array}{l}\text { Teeth enamel } \\
\text { and dentine }\end{array}$ & $\begin{array}{l}\text { Reduction of hard dental tissues microhardness and its influence on enamel } \\
\text { caries' resistance }\end{array}$ \\
\hline 13 & $\begin{array}{l}\text { Revelation of enamel demineralisation } \\
\text { centres on the border with filling material }\end{array}$ & Teeth enamel & Revelation of caries liability at the enamel region \\
\hline 14 & Definition of unsatisfactory filling & Teeth enamel & Revelation of caries liability at the enamel region \\
\hline 15 & $\begin{array}{l}\text { Definition in periodontal treatment } \\
\text { requirement }\end{array}$ & $\begin{array}{l}\text { Periodontal } \\
\text { tissues }\end{array}$ & $\begin{array}{l}\text { Local variation of } \mathrm{pH} \text { caused by gingival fluid, bacterial component in oral } \\
\text { cavity, and exponentiation of caries development }\end{array}$ \\
\hline 16 & Definition of gingiva inflammation level & $\begin{array}{l}\text { Periodontal } \\
\text { tissues }\end{array}$ & $\begin{array}{l}\text { Local variation of } \mathrm{pH} \text { caused by gingival fluid, bacterial component in oral } \\
\text { cavity, and exponentiation of caries development }\end{array}$ \\
\hline 17 & Definition of gingiva angiostaxis degree & $\begin{array}{l}\text { Periodontal } \\
\text { tissues }\end{array}$ & $\begin{array}{l}\text { Local variation of } \mathrm{pH} \text { caused by gingival fluid, bacterial component in oral } \\
\text { cavity, and exponentiation of caries development }\end{array}$ \\
\hline 18 & Definition of combined saliva viscosity & Oral fluid & Reduction of enamel caries resistance, remineralising ability of oral fluid \\
\hline 19 & Definition of combined saliva acidity & Oral fluid & Reduction of enamel caries resistance, remineralising ability of oral fluid \\
\hline 20 & Definition of salivation rapidity & Oral fluid & Reduction of enamel caries resistance, remineralising ability of oral fluid \\
\hline 21 & $\begin{array}{l}\text { Definition of status of buffered saliva } \\
\text { characteristic }\end{array}$ & Oral fluid & Reduction of enamel caries resistance, remineralising ability of oral fluid \\
\hline 22 & $\begin{array}{l}\text { Definition of oral fluid microcrystallisation } \\
\text { exponent }\end{array}$ & Oral fluid & Reduction of enamel caries resistant, remineralising ability of oral fluid \\
\hline 23 & Bacterioscopy & $\begin{array}{l}\text { Microflora of } \\
\text { oral cavity }\end{array}$ & $\begin{array}{l}\text { Violation of bacteritic balance in oral cavity, activation of tentatively } \\
\text { pathogenic and pathogenic microorganisms, reduction of enamel caries } \\
\text { resistance }\end{array}$ \\
\hline 24 & Cytology & $\begin{array}{l}\text { Microflora of } \\
\text { oral cavity }\end{array}$ & $\begin{array}{l}\text { Violation of bacteritic balance in oral cavity, activation of tentatively } \\
\text { pathogenic and pathogenic microorganisms, reduction of enamel caries } \\
\text { resistance }\end{array}$ \\
\hline
\end{tabular}




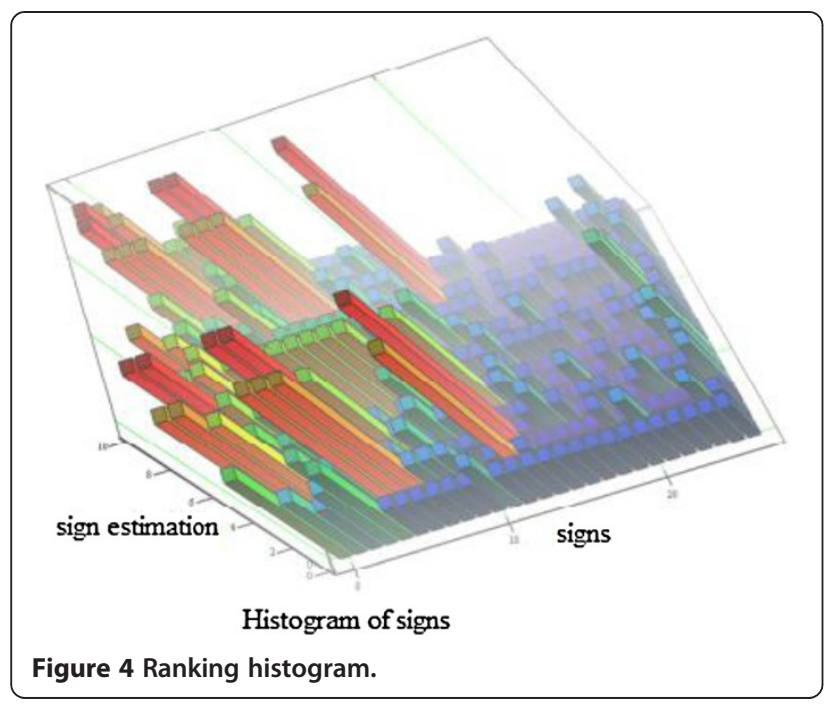

To develop the most complete list of indicators that predicts the occurrence of caries process, we used the data of scientific, methodological literature and collaboration of the Therapeutic Dentistry Department staff. Thus, the list of symptoms of potentially possible caries was finally created [85]. We have referred the following diagnostic receptions to methods of caries forecasting (Table 1).

Submitted list of diagnostic methods allows understanding the main aspects of caries process, assesses the risk of its development, and also suggests the possibility of emergency prevention and/or caries progression in the nearest future [86-88].

However, the usage by dentist of such a large range of 24 forecasting methods, primarily qualitative type, is not conducive to effective diagnostic and therapeutic processes in caries prevention because of the following: firstly, the usage of a large number of indicators complicates work at the practical appointment in the diagnosis statement; secondly, in our view, it is a kind of diagnostic liability and not only raises up the reliability of diagnosis, but apparently in some cases even reduces it; thirdly, some data duplicate each other, describing the same sign of tooth caries.

In this paper, to assess the 24 signs of predicting caries and to highlight the most significant of these, we used the method of a prior decent ranking, which allows to objectively assess the subjective opinions of specialists (experts) [89-91]. Leading specialists from the Therapeutic Dentistry Department of VSMA in N.N. Burdenko, who have already had a doctorate degree or $\mathrm{PhD}$ in dealing with theoretical and practical problems of caries pathology and with work experience from 15 to 38 years, have been recruited to the expert committee. Fifteen experts were asked to complete a questionnaire, ranking the techniques where the caries susceptibility rates were assessed by the level of their influence, decrease on the emergence and development of the pathological process, and also to place these techniques in sequential order while examining the patient. Dichotomy (sequential decomposition of disease signs hyperspace in two areas by cutting planes) was applied for improving the efficiency of ranking method. Thus, the whole summation of predictive caries signs was divided by each of the experts into two groups, one of which, according to experts, would consist of parameters, which in a greater degree of influence on the caries process occurrence, and the second, from less affected. Then, each group of indicators again was divided into two groups, etc. - as long as the number of

Table 2 List of the main caries prediction methods and sequence of conducting dental examination

\begin{tabular}{cll}
\hline Number & Method & Structure \\
\hline 1 & Polling & Oral cavity \\
2 & Inspection, probe & Dentition \\
3 & Definition of the caries intensity & Oral fluid \\
4 & Definition of hydrogen ion exponent in oral fluids & Teeth enamel \\
5 & Definition of hygienic status of the oral cavity & Teeth enamel \\
6 & Definition of the tooth plaque cariogenicity & Teeth enamel \\
7 & Acidic enamel biopsy & Teeth enamel \\
8 & Clinical evaluation of remineralisation speed in enamel (CDERS test) & Periodontal tissues \\
9 & Definition of enamel functional status (TER test) & Teeth enamel \\
10 & Definition of gingivitis index & Mucous membrane of oral cavity \\
11 & Bacterioscopy & Mucous membrane of oral cavity \\
12 & Cytology & Teeth enamel and dentine \\
14 & Revelation of enamel demineralisation centres on the border with filling material & Teeth enamel \\
\hline
\end{tabular}


features was not more than five. In this case, ranking the options in each group and overall was more genuine. In accordance with the parameter importance, its place in the sequence of diagnostic procedures was determined [92,93].

By the combination of the experts' opinion, a matrix of rank was formed, containing the matching rank. According to research results, a ranking histogram was built (Figure 4), where the horizontal axis plotted the corresponding numbers of diagnostic methods of caries prediction in descending order according to the degree of its self-descriptiveness and the ordinate for each indicator delayed generalised rank-sum value, which essentially characterises the measurement consistency of expert physicians in assigning to this parameter-given rank.

The histogram shows that there is an uneven distribution of signs and decrease in the factors influence which is not homogeneous and therefore, the most essential factor may be separately analysed. Thus, according to the experts, from the 24 indicators, 14 that are more informative are shown in Table 2 in order which, in the expert committee opinion, is the most preferred for dental examination.

\section{Conclusions}

In conclusion, the list of the most informative prognostic caries criteria included those signs, which are often met and the identification of these do not pose a significant challenge for the dentist. It is possible to use the highlighted results of the most significant predicting caries factors for (a) targeting specification of patients' dental status and its distribution to the prevention groups; (b) planning, based on the indicators data, individual preventive measures, preventing caries process; and (c) assessing the effectiveness of prevention programmes and their timely correction [94-96].

\section{Competing interest}

The authors declare that they have no competing interests.

\section{Authors' contributions}

AAK carried out the molecular genetic studies, participated in the sequence alignment, conceived the study, participated in its design and coordination, and drafted the manuscript, IAB participated in the sequence alignment and designing of the study, and performed the statistical analysis. YAl carried out the molecular genetic studies, participated in the sequence alignment, and drafted the manuscript. NSM also participated in the sequence alignment. DAK carried out the molecular genetic studies, participated in the sequence alignment, and drafted the manuscript. All authors read and approved the final manuscript.

\section{Author's information}

AAK is a coordinator of specialised section in dentistry (DPPPD) of EPMA.

Received: 14 April 2013 Accepted: 27 May 2013

Published: 26 June 2013

\section{References}

1. Golubnitschaja O, Swanton C, Danesi R, Costigliola V: Promoting Predictive, Preventive and Personalised Medicine: European event of global importance. EPMA J 2011, 2:131-136.
2. Golubnitschaja O, Costigliola V, EPMA: General report \& recommendations in Predictive, Preventive and Personalised Medicine 2012: White Paper of the European Association for Predictive, Preventive and Personalised Medicine. EPMA J 2012, 3:14.

3. Kunin AA, Belenova IA, Olejnik OI, Pankova SN, Erina SV, Ippolitov JA, Lepehina LI: Individual'naja profilaktika kariesa u vzroslyh. Uchebnometodicheskoe posobie s grifom UMO. Voronezh; 2005:174.

4. Silverstone LM: Structure of carious enamel, including the early lesion. Oral Sci Rev 1973, 3:100-60.

5. Kunin AA, Belenova IA, Selina OB: Rol' menedzhmenta v povyshenii jeffektivnosti meroprijatij kompleksnoj sistemy profilaktiki kariesa. Sistemnyj Analiz i Upravlenie v Biomedicinskih Sistemah 2008, 7(1):103-105.

6. Sadovskij W, Belenova IA, Shumilovich BR: Primenenie vysokotehnologichnyh metodov $\mathrm{v}$ diagnostike zabolevanij zubov. Institut Stomatologii 2008, 38(1):74-75.

7. Belenova IA: Rol' vodorodnogo pokazatelja rotovoj zhidkosti i zubnogo naleta v programmah profilaktiki patologii parodonta. Sistemnyj Analiz i Upravlenie v Biomedicinskih Sistemah 2007, 6(4):952-954.

8. Bansal K, Gauba K, Tewari A, Chawla HS, Sahni A: In vivo remineralization of artificial enamel carious lesions using a mineral-enriched mouthrinse and a fluoride dentifrice: a polarized light microscopic comparative evaluation. J Indian Soc Pedod Prev Dent 2010, 28:264-70.

9. Belenova IA: Primenenie vysokih tehnologij v diagnostike zabolevanij zubov. Sistemnyj Analiz i Upravlenie v Biomedicinskih Sistemah 2008, 7(4):1070-1073.

10. Kunin AA, Lepehina LI, Shumilovich BR: Sovremennye metody diagnostiki i lechenija zabolevanij zubov: ucheb.-metod. posobie. Voronezh: Amazon; 2007:25.

11. Kunin A, Belenova I: Our experience in prophylaxis of recurrence (second) caries, Papers of the 3rd Pan-European Dental Congress: December 9-10 2009. :30-31.

12. Brown WE: Physicochemical mechanisms in dental caries. J Dent Res 1974, 53:204-255.

13. Sadovskij W, Belenova IA, Shumilovich BR: Primenenie vysokotehnologichnyh metodov v diagnostike zabolevanij zubov. Institut Stomatologii 2008, 1:74-75.

14. Fejerskov O, Nyvad B: Dental caries in the aging individual. In Textbook of Geriatric dentistry. 2nd edition. Edited by Holm-Pederson P, Loe H. Belin: Munksgaard; 1996

15. Belenova IA: Individual'naja profilaktika kariesa u vzroslyh. Voronezh: Dissertation Abstract of Doctor of Medical Science; 2010:37-40.

16. Bazin AK, Zheleznyj PA, Melent'eva EG: Innovacionnyj podhod v lechenii kariesa zubov na stadii demineralizacii. Zhurnal Jeksperimental'noj i Klinicheskoj Mediciny 2006, 1(2):181-183.

17. Axelsson P: Diagnosis and Risk Prediction of Dental Caries. Quintessence Publishing; 2000:307.

18. Larsen MJ, Richards A: The influence of saliva on the formation of calcium fluoride-like material on human dental enamel. Caries Res 2001, 35:57-60.

19. Ippolitov Ju A: Klinicheskaja ocenka i differencial'naja diagnostika nachal'noj stadii karioznogo processa jemali i cementa zuba. Vestnik Novyh Medicinskih Tehnologij 2011, XVIII(2):186-188.

20. Ippolitov Ju A, Moiseeva NS: Rannjaja diagnostika i lechebnoprofilakticheskaja terapija nachal'nogo kariesa zuba. Tihookeanskij Medicinskij Zhurnal 2013, 1:34-36.

21. Lussi A: Comparison of different methods for the diagnosis of fissure caries without cavitation. Caries Res 1993, 27:409-416.

22. Leont'ev VK: Osobennosti mikrostruktury jemali i dentina intaktnyh i karioznyh zubov. Materialy. M 2002:59-62.

23. Ippolitov Ju A, Azarova NS, Ju II: Lechebno-profilakticheskie meroprijatija dlja predotvrashhenija karioznogo processa tverdyh tkanej zuba. Periodicheskij Teoreticheskij i Nauchno-Prakticheskij Zhurnal 2011, XVIII(2):184-186.

24. Kunin AA, Belenova IA, Olejnik OI, Kunin DA, Moiseeva NS: Nanotehnologicheskie morfohimicheskie aspekty jemali zuba. Zhurnal Stomatologija, Baltic Dental and Maxillofacial 2012, 14(8):12-15. ISSN 1392-8589.

25. Kunin AA, Leontiev VK, Popova TA, Koretskay IV, I Ippolitov Yu A, Zoibelmann M, Agapov BL, Nekrylov VA: Scanning Electron Microscopy and Microchemical Analysis of Enamel and Caries Under Low-intensity Laser Irradiation Influence. Amsterdam: European biomedical optics week, BIOS Europe; 2000:43. N 4159. 
26. Kunin AA: Topologicheskie osobennosti mineral'nyh i organicheskih sostavljajushhih jemali zuba. Vestnik Instituta Stomatologii: Voronezh; 2008, 6:4-6.

27. Leont'ev VK, Kunin AA, Popova TA, Ippolitov Ju A, Koreckaja IA, Kljuchnikova EA: Osobennosti mikrostruktury jemali i dentina intaktnyh i karioznyh zubov Sovremennye problemy formirovanija uchebnoj dejatel'nosti studentov medicinskogo vuza. Voronezh: sbornik materialov of Voronezh N.N. Burdenko State Medical Academy; 2002:59-62.

28. Ippolitov JA: Znachenie organicheskoj sostavljajushhej tverdyh tkanej zuba dlja profilaktiki destruktivnogo processa. Vestnik Instituta Stomatologii: Voronezh 2006, 2:41-46.

29. Ippolitov JA, Je.G B, Gorshkova OM: Topohimija i soderzhanie kationnogo belka v strukturah zuba cheloveka. Novosti Klinicheskoj Citologii 2001, 5(3-4):162-164.

30. Kunin AA, Leontiev VK, Kazmina SG, Dergounova El: Elimination technique of dental plaque cariogenicity. 1997. http://www.ntpo.com/patents_medicine/ medicine_17/medicine_421.shtml.

31. Zaura E, Bujis MJ, ten Cate JM: The effects of the solubility of artificial fissures on plaque $\mathrm{pH}$. J Dent Res 2002, 81:567-571.

32. Kunin AA, Shelkovnikova SG, Pankova SN, Ippolitov JA, Popova TA, Azarova NS: Vlijanie modulirovannogo svetovogo izluchenija na kariesogennost' zubnogo naleta, Primenenie lazerov v medicine i biologii: Materialy XXXIV mezhdunarod. nauch.-prakt. konf., 6-9 okt. 2010 g. Sudak; 2010:27-29.

33. Ippolitov JA, Ju I, Ippolitov ES, Ippolitov IJ, Kalinina ES: Rol' kachestvennogo sostava zubnogo naleta $v$ izmenenii rezistentnosti jemali zubov cheloveka k razvitiju karioznogo processa. Allergologija i Immunologija 2011, 123(1):12.

34. Ippolitov JA: Profilakticheskie aspekty kariesologii. Sovremennye tehnologii v terapevticheskoj stomatologii: materialy nauch. simpoziuma, 12-13 fevr. Voronezh; 2002:38-41.

35. Ippolitov Ju A: Novye perspektivy v individual'noj profilaktike kariesa. Materialy XVI Vseros. nauch.-prakt. konf.; Tr. XI sezda Stomatologicheskoj associacii Rossii i VIII sezda stomatologov Rossii. M. 2006:180-183.

36. Zhang YP, Kent RL Jr, Margolis HC: Enamel demineralization under driving forces found in dental plaque fluid. Eur J Oral Sci 2000, 108:207-213.

37. Ippolitov Ju A, Vusataja EV: Razrabotka i ocenka jeffektivnosti profilaktiki zabolevanij tverdyh tkanej zubov s uchetom mediko-social'nyh faktorov riska. Zhurnal Teoreticheskoj i Prakticheskoj Mediciny 2008, 6(1):64-66.

38. Ippolitov JA, Bykov JG: Gistohimija organicheskih komponentov zubov cheloveka. Obekt i problemy analiza. Morfologija (Arhiv anatomii, gistologii i jembriologii) 53 2009, 2:133.

39. Ippolitov Ju A: Izuchenie organicheskoj sostavljajushhej jemali intaktnogo chelovecheskogo zuba metodom infrakrasnoj spektroskopii. Sistemnyj Analiz i Upravlenie v Biomedicinskih Sistemah 2009, 8(4):882-884.

40. Ippolitov JA, Azarova NS: Lechebno-profilakticheskie meroprijatija dlja predotvrashhenija karioznogo processa tverdyh tkanej zuba. Vestnik Novyh Medicinskih Tehnologij 2011, XVIII(2):184-186.

41. Kunin AA, Ippolitov JA, Belenova IA, Olejnik IA: Rol' morfo-himicheskih issledovanij tverdyh tkanej zubov $v$ formirovanii teoreticheskih predposylok profilaktiki kariesa. Zhurnal Teoreticheskoj i Prakticheskoj Mediciny 2008, 6(1):72-74.

42. Kunin AA, Ippolitov YA, Bykov EG: A tooth biopolymer may provide a basis for physiologic protection against caries. RAMA 2007, 2(3):24.

43. Kunin AA: Sovremennye metody diagnostiki i lechenija zabolevanij zubov: ucheb.-metod. posobie (2 izd.). Voronezh; 2007:25.

44. Fedotov DJ, Belikov AV, Kretcer JL, Moroz BT: Izuchenie sootnoshenija Sa/R v intaktnoj i karioznoj jemali i dentine zubov posle vozdejstvija YAG:Er lazernym izlucheniem. Institut stomatologii 2008, 1(38):110-112.

45. Kunin A, Leont'ev VK, Ippolitov JA: Mikrohimicheskie aspekty mineral'nogo obmena tverdyh tkanej zuba $v$ uslovijah razvitija karioznogo processa. Materialy XII i XIII Vseros. nauch.-prakt. konf. i tr. IX sezda Stomatologicheskoj associacii Rossii. - M. ; 2004:58-60.

46. ten Cate JM: Remineralization of deep enamel dentine caries lesions. Aust Dent J 2008, 53:281-5.

47. Batjukov NM, Ivanova GG, Kasumova MK, Mchedlidze TS h, Tihonov JP. Sistemnyj analiz tverdyh tkanej zubov na osnove opticheskogo i jelektricheskogo zondirujushhih signalov (Chast' I-III) / N.M. Batjukov. Institut Stomatologii 2007, 1(34):102-105.

48. Ippolitov JA: Organicheskaja matrica kak fiziologicheskij bar'er tverdyh tkanej zuba. Prikladnye Informacionnye Aspekty Mediciny 2000, 3:72-75.
49. Ippolitov JA: Znachenie organicheskoj sostavljajushhej tverdyh tkanej zuba dlja profilaktiki destruktivnogo processa. Vestnik Instituta Stomatologii 2006, 2:64-68.

50. Bykov JG, Ippolitov JA: Gistohimija biopolimerov zuba - novaja sfera nauchnoj dejatel'nosti v stomatologii. Sistemnyj Analiz i Upravlenie v Biomedicinskih Sistemah 2004, 3(3):48-49.

51. Ippolitov JA: Funkcional'naja morfologija jemali chelovecheskogo zuba. Vestnik Novyh Medicinskih Tehnologij 2010, XVII(2):56-58.

52. Rabuhina NA, Arzhancev AP: Rentgenodiagnostika $v$ stomatologii. $M$. Medicina. ; 2001

53. Loginova NK: Vozmozhnosti funkcional'noj diagnostiki v kariesologii. Novoe $v$ Stomatologii 2005, 4:40-41.

54. Ippolitov Ju A: Diagnostika ochagov nachal'noj stadii karioznogo processa jemali i cementa zuba $s$ ispol'zovaniem metodov jelektrometrii, fljuorescencii i rentgenografii. Obshherossijskij Nauchno-Prakticheskij Recenziruemyj Zhurnal, Medicinskij Alfavit 2011, 2:51-54.

55. Lussi A, Hibsi R, Paulus R: DIAGNOdent: an optical methods for caries detection. J Dent Res 2004, 83:80-83.

56. Ivanova GG: Diagnosticheskaja i prognosticheskaja ocenka jelektrometrii tverdyh tkanej zubov pri kariese. Avtoref Dis Kand Med Nauk 1984, 19

57. Ju LG: Lazerno-inducirovannaja fljuorescencija i rentgenospektral'nyj analiz karioznogo processa tverdyh tkanej zuba. Bjulleten Jeksperimental'noj Biologii i Mediciny 2010, 3:12-14.

58. Aleksandrov MT, Grudjanov Al, Masychev VI: Izuchenie intensivnosti fljuorescencii intaktnyh i patologicheski izmenennyh tkanej zuba. Novoe v Stomatologii 2000:26-32.

59. Darling $\mathrm{CL}$, Huynh GD, Fried D: Light scattering properties of natural and artificially demineralized dental enamel at $1310 \mathrm{~nm}$. J Biomed Opt 2006, 11:34023.

60. Barberı'a E, Maroto M, Arenas M, Silva CC: A clinical study of caries diagnosis with a laser fluorescence system. J Am Dent Assoc 2008, 139(5):572-9.

61. Jones RS, Fried D: Attenuation of 1310-nm and 1550-nm laser light through dental enamel. J Dent Res 2001, 80:527-797.

62. Angnes V, Angnes G, Batisttella M, Grande RHM, Loguercio AD: Clinical effectiveness of laser fluorescence, visual inspection and radiography in the detection of occlusal caries. Caries Res 2005, 39:490-495.

63. Ippolitov Ju A, Pankova SN, Shelkovnikova SG, Moiseeva NS, Borisova Je G: Rol' svetoinducirovannoj fljuorescencii i jelektrometrii v ocenochnoj harakteristike i remineralizujushhej terapii tverdyh tkanej zuba. Zhurnal Fundamental'nye issledovanija 2011, 9(3):408-410.

64. Kunin AA, Moiseeva NS: Terapevticheskie i predupreditel'nye mery profilaktiki kariesa na doklinicheskom jetape ego razvitija, Evropejskij Simpozium po predupreditel'noj stomatologii, Trudy po itogam vstrechi, 24 fevralja. Voronezh; 2012.

65. Kunin AA, Moiseeva NS, Kunin DA: Zavisimost' svetovyh harakteristik tverdyh tkanej zuba ot ego morfo-himicheskoj struktury, Vestnik instituta stomatologii (jubilejnyj vypusk), Materialy stomatologicheskogo kongressa po predupreditel'noj, profilakticheskoj i personificirovannoj stomatologii pod jegidoj ERMA, posvjashhennogo 55-letiju stomatologicheskogo fakul'teta VGMA im. N. N. Burdenko. Voronezh; 2012. No. 3 (15), nojabr', 2012 g.

66. Gul'ko EM: Ispol'zovanie metoda fibroopticheskoj transilljuminacii dlja diagnostiki kariesa u detej. Dostizhenija medicinskoj nauki Belorusi. 2005:23-27.

67. Ju K'm O, Nikolaev Al, Malysheva EA, Docenko AV, Stepanova TS Klinicheskoe primenenie sistemy inducirovannoj fluorescencii SOPROLIFE dlja diagnostiki i planirovanija lechenija kariesa zubov u detej i vzroslyh. Zhurnal Novoe v Stomatologii Obshherossijskij Nauchno-Prakticheskij Recenziruemyj Zhurnal, Medicinskij Alfavit 2011, 2.

68. Morozova OA: Jeksperimental'noe obosnovanie jekspress-metoda lazernoj fljuorescentnoj diagnostiki zabolevanij mikrobnoj prirody. Avtoreferat dissertatsiy kandidata medicinskich nauk, Dissertation Abstract. M. 2001:25

69. Jones RS, Darling CL, Featherstone JD, Fried D: Remineralization of in vitro dental caries assessed with polarization-sensitive optical coherence tomography. J Biomed Opt 2006, 11:014016.

70. Stookey GK: Optical methods - quantitative light fluorescence. J Dent Res 2004, 83:84-88.

71. Zajceva EV: Razrabotka metoda fljuorescentnoj diagnostik sostojanija tverdyh tkanej zuba pri karioznom porazhenii (jeksperimental'no-klinicheskoe issledovanie).

Dis kand med nauk M 2000, 188. 
72. Harris R, Nicoll AD, Adair PM, Pine CM: Risk factors for dental caries in young children: a systematic review of the literature. Community Dental Health 2004, 21:71-85.

73. Ippolitov JA, Vusataja EV: Razrabotka i ocenka jeffektivnosti profilaktiki zabolevanij tverdyh tkanej zubov s uchetom mediko-social'nyh faktorov riska. Zhurnal Prakticheskoj i Teoreticheskoj Mediciny 2008, 6(1):64-67.

74. Kunin AA, Zojbel'man M, Ippolitov JA: Novye aspekty v lechenii i profilaktike neoslozhnennogo kariesa Stavropol: Novoe v teorii i praktike stomatologii: sb. nauch. rabot uchenyh-stomatologov Rossii. 2002:105-111.

75. Imai K, Shimada Y, Sadr A, Sumi Y, Tagami J: Noninvasive cross-sectional visualization of enamel cracks by optical coherence tomography in vitro. J Endod 2012, 38:1269-74.

76. Chibisova MA: Cifrovaja i plenochnaja rentgenografija $v$ ambulatornoj stomatologii. Moscow: MEDpress-inform; 2004:34-36.

77. Vorob'ev Ju I: Rentgenodiagnostika v praktike vracha-stomatologa. M. Moscow: MEDpress-inform; 2004:112.

78. Ippolitov Ju A: Razrabotka i ocenka jeffektivnosti metodov normalizaci obmennyh processov tverdyh tkanej zuba $v$ uslovijah razvitija karioznogo processa: avtoref. dis... . d-ra med. nauk. Voronezh: Ippolitova; 2012:35.

79. Ippolitov JA, Lepehina LI, Burdina GA, Stepanjan NA: Znachenie klinicheskoj gistohimii v stomatologicheskoj praktike. Sistemnyj Analiz i Upravlenie v Biomedicinskih sistemah 2006, 5(1):64-68.

80. Bader J, Shugars B: Systematic reviews of selected dental caries diagnostic and management methods. J Dent Ed 2001, 65:960-968.

81. Haak R, Wicht MJ, Hellmich M, Gossmann A, Noack MJ: The validity of proximal caries detection using magnifying visual aids. Caries Res 2002, 36:249-55.

82. Kunin AA, Olejnik OI, Belenova IA, Pankova SN, Ippolitov JA, Sushhenko AV, Shumilovich BR: Primenenie sistemy avtomatizirovannoj diagnostiki dlja optimizacii vybora parametrov lazernoj terapii kariesa, Lazer i informacionnye tehnologii v medicine 21 v. materialy mezhdunarod. konf. i nauch.-prakt. konf. Sev.-Zap. reg. RF. - SPb., 2001. - Ch. 1. - S. 283-284. ; 2001:283-284. Ch. 1. - S.

83. Kunin AA, Belenova IA, Erina SV, Pankova SN, Lepehina LI, Olejnik OI, Savenok EN: Vysokie tehnologii v diagnostike i lechenii zabolevanij zubov i parodonta. Sistemnyj analiz i Upravlenie v Biomedicinskih Sistemah 2004, 3(1):45-49

84. MacRitchie HM, Longbottom C, Robertson M, Nugent Z, Chan K, Radford JR, Pitts NB: Development of the Dundee Caries Risk Assessment Model (DCRAM) - risk model development using a novel application of CHAID analysis. Comm Dent Oral Epidemiol 2012, 40:37-45.

85. Kunin AA, Pankova SN, Lepjohina LI, JuA I, Erina SV, Belenova IA, Olejnik OI: Prognozirovanie issledovanij $v$ terapevticheskoj stomatologii na osnove dostizhenij nauki v oblasti diagnostiki i lechenija zabolevanij zubov, parodonta i slizistoj obolochki polosti rta, Sb. materialov II nauch.-prakt. konf., posvjashh. pamjati prof. E.E. Platonova. - M. 2004:67-70.

86. Leont'ev VK: Karies zubov - slozhnye i nereshennye problemy. Novoe $\mathrm{V}$ Stomatologii 2003, 6:6-8.

87. Kunin AA: Rol' morfo-himicheskih issledovanij tverdyh tkanej zubov v formirovanii teoreticheskih predposylok profilaktiki kariesa. Zhurnal Prakticheskoj i Teoreticheskoj Mediciny 2008, 6(1):72-75.

88. Olejnik Ol: Primenenie vysokih tehnologij v lechenii kariesa zubov. Sb. rabot 68-j itog. nauch. sessii KGMU i otd. med. biol. nauk CCh nauch. centra RAMN. - Kursk:KGMU. 2002:296-297. Ch. 1.

89. Kunin AA, Belenova IA, Shelkovnikova SG, Pankova SN, Kozhuhov AV: Znachenie individual'nogo podbora zubnoj pasty Colgate v profilaktike kariesa u vzroslyh. Stomatologicheskoe obozrenie. M 2003, 1:5-7.

90. Kunin AA, Belenova IA, Olejnik OI, Sushhenko AV, Kudrjavcev OA: Profilaktika zabolevanij parodonta $v$ ramkah programmy individual'noj profilaktiki kariesa u vzroslyh. Sb. materialov XVI Vseros. nauch.-prakt. konf., tr. XI sezda StAR, 8 sezda stomatologov Rossii. - M. 2006:198-200.

91. Ricketts DN, Kidd EA, Smith BG, Wilson RF: Clinical and radiographic diagnosis of occlusal caries: a study in vitro. J Oral Rehabil 1995, 22:15-20.

92. Borisenko LG, Tihonova SM: Metod 'kariogramma' v klinicheskom prognozirovanii kariesa zubov. Klinicheskaja Stomatologija 2004, 1:14-16.

93. Bowen $\mathrm{WH}$ : Do we need to be concerned about dental caries in the coming millennium? Crit Rev Oral Biol Med 2002, 13:126-131.

94. Kunin AA, Belenova IA, Ippolitov JA, Pankova SN, Kudrjavcev OA, Kunin VA: Novye aspekty plombirovanija zubov. Zhurnal Teoreticheskoj i Prakticheskoj Mediciny 2003, 16(1):43-48.
95. Zojbel'mann MV: Upravlenie kachestvom lechebno-diagnosticheskogo processa v stomatologicheskoj klinike. Sistemnyj Analiz i upravlenie v Biomedicinskih Sistemah 2005, 4(2):185-188.

96. Gao XJ, Fan Y, Kent RL Jr, Van Houte J, Margolis HC: Association of caries activity with the composition of dental plaque fluid. J Dent Res 2001, 80:1834-1839.

doi:10.1186/1878-5085-4-19

Cite this article as: Kunin et al:: Predictive research methods of enamel and dentine for initial caries detection. The EPMA Journal 2013 4:19.

\section{Submit your next manuscript to BioMed Central and take full advantage of:}

- Convenient online submission

- Thorough peer review

- No space constraints or color figure charges

- Immediate publication on acceptance

- Inclusion in PubMed, CAS, Scopus and Google Scholar

- Research which is freely available for redistribution

Submit your manuscript at www.biomedcentral.com/submit
C Biomed Central 